\title{
A rectus diastasis prevalenciája, lehetséges rizikófaktorai és szövődményei
}

\author{
Gitta Stefánia ${ }^{1}$ - Magyar Zoltán dr. ${ }^{2}$ - Tardi Péter ${ }^{3}$ - Füge Istvánné ${ }^{4}$ \\ Járomi Melinda dr. ${ }^{1}$ - Ács Pongrác dr. ${ }^{1}$. Garai János $\mathbf{d r} .^{5}$ \\ Bódis József dr. ${ }^{4}$ - Hock Márta dr. ${ }^{1}$ \\ ${ }^{1}$ Pécsi Tudományegyetem, Egészségtudományi Kar, Fizioterápiás és Sporttudományi Intézet, Pécs \\ ${ }^{2}$ Péterfy Sándor utcai Kórház-Rendelőintézet és Baleseti Központ, Szülészeti és Nőgyógyászati Osztály, Budapest \\ ${ }^{3}$ Vasútegészségügyi Nonprofit Közhasznú Kft., Egészségügyi Központ, Mozgásszervi Rehabilitációs Intézet, \\ Harkány \\ ${ }^{4}$ Pécsi Tudományegyetem, Általános Orvostudományi Kar, Klinikai Központ, \\ Szülészeti és Nőgyógyászati Klinika, Pécs \\ ${ }^{5}$ Pécsi Tudományegyetem, Általános Orvostudományi Kar, Transzlációs Medicina Intézet, Pécs
}

\begin{abstract}
Bevezetés: Leggyakrabban a terhesség harmadik trimeszterétől jelentkezik a rectus diastasis, amellyel kapcsolatban csekély információ áll rendelkezésünkre. Célkitüzés: Célunk volt meghatározni a rectus diastasis hazai előfordulásának gyakoriságát, a lehetséges rizikófaktorokat, megvizsgálni a derékfájással, vizeletinkontinenciával és az életminőséggel való kapcsolatát. Módszer: Az interrectus távolságát digitális caliperrel 200 olyan nőnél mértük meg, akik kitöltötték a saját készítésû́ rectus diastasis, továbbá az SF-36, az Oswestry Disability Index és az International Consultation on Incontinence Modular Questionnaire - Urinary Incontinence Short Form kérdőíveket. Eredmények: A prevalencia 46,5\%-os lett. A rizikófaktorok közül csak a szülések száma és az interrectusrés között volt szignifikáns kapcsolat. Jelentős különbséget találtunk azonban az életminőség, a derékfájás és a vizeletinkontinencia kapcsán a normál és a kóros csoport tagjai között. Következtetések: A külföldi szakirodalommal megegyeztek eredményeink, amelyek alapján elmondhatjuk, hogy a rectus diastasis majdnem minden második szült nőt érint. Az állapot hajlamosíthat a derékfájásra és a vizeletinkontinenciára, amelyből egy csökkent életminőség származhat. Orv. Hetil., 2017, 158(12), 454460.
\end{abstract}

Kulcsszavak: rectus diastasis, rizikófaktor, derékfájás, vizeletinkontinencia, életminőség

\section{Prevalence, potential risk factors and sequelae of diastasis recti abdominis}

Introduction: There is scant knowledge on diastasis recti which occurs mostly in $3^{\text {rd }}$ trimester of pregnancy. Aim: Our aim was to assign the prevalence of diastasis recti and the possible risk factors and to investigate its association with some chronical diseases, like low back pain and urinary incontinence. Method: 200 women's interrectus distance was measured who filled out a self-made diastasis recti questionnaire, the SF-36, Oswestry Disability Index and the International Consultation on Incontinence Modular Questionnaire - Urinary Incontinence Short Form questionnaires. Results: Prevalence of the condition was 46.5\%. In case of risk factors, relationship between number of deliveries and interrectus distance was significant. We found a significant difference in quality of life, in presence of low back pain and urinary incontinence between the normal and the abnormal group. Conclusions: In line with the literature we found, that diastasis recti can predispose on serious sequelae, hence on decreased quality of life.

Keywords: diastasis recti abdominis, risk factor, low back pain, urinary incontinence, quality of life

Gitta, S., Magyar, Z., Tardi, P., Füge, I., Járomi, M., Ács, P., Garai, J., Bódis, J., Hock, M. [Prevalence, potential risk factors and sequelae of diastasis recti abdominis]. Orv. Hetil., 2017, 158(12), 454-460.

(Beérkezett: 2017. január 10.; elfogadva: 2017. január 27.) 


\section{Rövidítések}

$\mathrm{BMI}=$ testtömegindex; DRA $=$ rectus diastasis; ICIQ-UI $/ \mathrm{SF}$ = International Consultation on Incontinence Modular Questionnaire - Urinary Incontinence Short Form; IRD = interrectus-távolság; KSH = Központi Statisztikai Hivatal; SD = szórás; SF-36 = 36-item Short Form Survey (életminőséget felméró kérdőív); $\mathrm{UH}=$ ultrahang; $\mathrm{WHO}=$ Egészségügyi Világszervezet

A musculus rectus abdominis két különálló részét összekötő linea alba körülbelül fél inch széles $(\sim 1,3 \mathrm{~cm})$ és edzett hasizom esetén szabad szemmel is jól megfigyelhető [1]. A várandósság harmadik trimeszterében egyes vizsgálatok szerint 66\%-ban [2], más kutatások szerint 100\%-ban - jelentkezik az egyenes hasizmok szétválása a linea alba mentén, amit rectus diastasisnak (diastasis recti abdominis - DRA) nevezünk [3]. A fellépő rés nagysága nagymértékben meghatározó. Kialakulhat kisebb méretú diastasis $(\sim 28-30 \mathrm{~mm})$, amelynek természetes regenerációjára nagy esély van, de jelentkezhet nagyobb távolság is $(\sim 58-60 \mathrm{~mm})$, amely beavatkozás nélkül már nem képes regenerálódni $[4,5]$.

A WHO adatai szerint 2013-ban ezer före vetítve átlag 19,5 szülés történt. Ez összesítve naponta 360000 szülést jelent a világon, vagyis másodpercenként négy gyermek látja meg a napvilágot. Ez alapján ugyanennyi terhességrőll is beszélhetünk, ami azt jelenti, hogy évente több mint 131 millió várandós nő lehet potenciálisan kitéve a rectus diastasisnak [6]. A KSH adatai szerint hazánkban 2015-ben 91 690, 2014-ben 91 510 gyermek született, ami közel százezer nő lehetséges érintettségét veti fel [7].

A rectus diastasis prevalenciáját illetően pontos hazai adatok még nem állnak rendelkezésre, így csak következtetni tudunk a külföldi szakirodalmak alapján, hogy valószínúleg Magyarországon is 35-60\% közé tehető az állapot post partum előfordulása [8]. Bár a nemzetközi szakirodalom még nem egyezett meg a kezelés során alkalmazandó protokollban, több cikk is foglalkozik a rectus diastasis előfordulási arányával, mérésével és kezelési lehetőségeivel [2-5, 9-11]. A lehetséges rizikófaktorok kapcsán nem sikerült még egyértelmúen bizonyítani, hogy a hormonális változásokon, illetve a növekvő méhen és magzaton túlmenően mi állhat még az állapot hátterében $[2,3]$. Amennyiben a rectus diastasis nem kerül diagnosztizálásra, ezáltal kezelésre sem, hosszú távon megváltoztathatja a nő testtartását [2]. Ennek kapcsán kialakulhat derékfájás, amely jól ismert szövődménye a rectus diastasisnak $[3,12,13]$. A mély hasizmok és a medencefenék-izmok szinergizmusban múködnek egymással, vagyis egyik izom kontrakciója során a másik növeli annak hatékonyságát. E szinergista kapcsolat miatt a rectus diastasis következtében gyengült hasizomfunkciók kihatással lehetnek a medencefenék-izmok kontrakciójára is, ami vizeletinkontinencia megjelenéséhez vezethet [14].
Vizsgálatunk célja volt meghatározni a perinatalis időszakban lévő nőknél a rectus diastasis prevalenciáját, illetve nagyságát. Másrészt megvizsgáltuk az állapot lehetséges rizikófaktorait, úgymint életkor, haskörfogat, testtömegindex (BMI), terhesség alatti súlygyarapodás, várandósság alatti fizikai aktivitás mértéke, a szülés módja és ideje, az újszülött születési súlya, a terhességek és a szülések száma. Továbbá felmértük a rectus diastasisban szenvedôk életminőségét, valamint az állapot derékfájással és vizeletinkontinenciával való esetleges kapcsolatát.

\section{Módszer}

Klinikai vizsgálatunkat 2015. január 5-től 2016. január 4-ig végeztük, amely során véletlenszerú, kényelmi mintavételi eljárást alkalmaztunk. A méréseket Budapesten, a Péterfy Sándor Utcai Kórház Szülészeti és Nőgyógyászati Osztályán, illetve Pécsett, a Szülészeti és Nőgyógyászati Klinikán végeztük. A vizsgálat kutatásetikai engedélyszámai: 1/2016 (VIII. 9.), amelyet az Uzsoki utcai és Péterfy Sándor utcai Kórházak Közös Regionális Tudományos és Kutatásetikai Bizottsága adott ki Budapesten, illetve 6303., amelyet a Pécsi Tudományegyetem, Klinikai Központ, Regionális és Intézményi Kutatásetikai Bizottság adott ki Pécsett. A közlemény nem sérti a Helsinki, valamint a Tokiói deklaráció követelményeit.

A tanulmányban olyan nók vehettek részt, akiknek korábban már volt legalább egy terhességük, és életkoruk 18 és 50 év között volt. A mérésbő́l kizártuk azokat a nőket, akik nem voltak képesek az interrectusrés vizsgálatához szükséges fej- és vállemelés kivitelezésére, illetve azokat, akik a szüléshez kapcsolódó érzéstelenítés miatt nem állhattak fel, ugyanis a haskörfogat adatait álló helyzetben vettük fel. A mérések alatt 312 nő adatait gyújtöttük össze. Az adatelemzés során kizártuk azokat a résztvevőket, akik a kérdőívek nem minden kérdésére adtak választ vagy hiányos választ adtak, így végül 200 fó adatait tudtuk értékelni. A továbbiakban egyes statisztikai próbák elvégzésekor a mintát két csoportra osztottuk az interrectus-távolság nagysága szerint. Az egyik csoport tagjai normál $(<30 \mathrm{~mm})$ mértékû réssel rendelkeztek, míg a második csoportba a normálnál nagyobb ( $\geq 30 \mathrm{~mm}$ ) távolságú réssel bíró egyének kerültek (1. ábra).

A vizsgálatban egy saját készítésû kérdőívet használtunk, amelyhez társítottunk további három standardizált kérdő́ivet, valamint a kutatást kiegészítettük egy fizikális vizsgálattal is. Saját készítésű kérdő́ivünk kitért a szociodemográfiai adatokra, a terhesség körüli időszak anamnézisére, különös tekintettel a haskörfogatra és a fizikai aktivitás mértékére, valamint szerepeltek kérdések a vizelettartási problémákra vonatkozóan is $[15,16]$. A 36item Short Form Survey (SF-36) kérdő́ivvel vizsgáltuk az alanyok életminőségét [17], az Oswestry Disability Index kérdő́ivvel a derékfájdalmat [18], továbbá az International Consultation on Incontinence Modular 


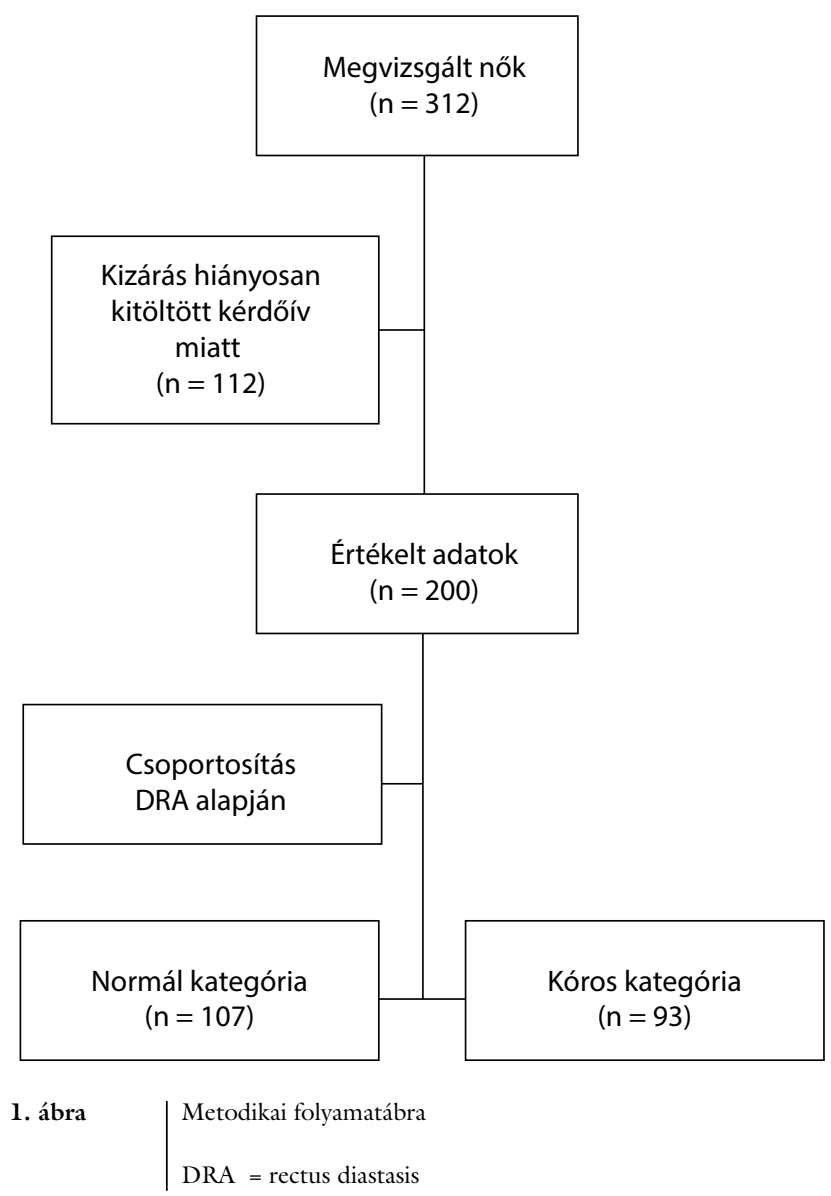

Questionnaire - Urinary Incontinence Short Form (ICIQ-UI/SF) kérdőívvel a vizeletvesztés súlyosságát [19].

A rectus diastasis mértékét egy digitális caliper segítségével határoztuk meg (Kingace, ISS szénszálas digitális caliper, 0-75/0,01 $\mathrm{mm} \pm 0,2 \mathrm{~mm})$. A vizsgálat kivitelezéséhez a beteg a hátára feküdt egy vízszintes felszínen úgy, hogy a feje alatt nem lehetett párna, térdét $90^{\circ}$-ban behajlította, kezeit a combjára fektette. A mérés kivitelezése előtt a vizsgáló egy centiméterszalag és egy toll segítségével bejelölte a hasfalon a mérési pontokat: közvetlen a köldök felső részénél, attól 5 , illetve $10 \mathrm{~cm}$-rel feljebb, valamint a köldök alsó részétól 2,5 és $5 \mathrm{~cm}$-rel lejjebb. Mivel a külföldi szakirodalomban nincsen megegyezés a mérési pontok tekintetében, ezért úgy választottuk meg azokat, hogy lefedjék a musculus rectus abdominis izomhasát $[3-5,9,10,13]$. Ez után a vizsgáló arra szólította fel a pácienst, hogy miközben szájon át kifújja a levegőt, emelje meg fejét, vállait, amíg a lapocka alsó szöglete éppen elemelkedik a talajtól, és közben csúsztassa az ujjait a térde irányába. Az alany egészen addig kitartotta ezt a pozíciót, amíg a vizsgáló az éppen adott mérési ponton ujjaival ki nem tapintotta a musculus rectus abdominis medialis határait, majd pedig a caliperrel le nem mérte a pontos interrectus-távolságot. Az egyes pontokon történő mérések között egy perc szünetet tartottunk, hogy megelőzzük az izmok kimerülését
[12]. Elisabeth Noble után kórosnak tekintettük az interrectus-távolságot abban az esetben, ha az elérte vagy meghaladta a $30 \mathrm{~mm}-\mathrm{t}$ [1]. Ez az érték megegyezett a sebészek által ajánlott paraméterekkel, akik a 27-30 mmes rést tekintik abnormálisnak [20,21].

A statisztikai elemzéshez az IBM-SPSS szoftver 22-es verzióját és a Microsoft Office Excel szoftver 2010-es változatát használtuk. Alkalmazott próbáink közt szerepelt a leíró statisztikán kívül az összefüggés-vizsgálat, az ANOVA-próba, a párosított t-próba, valamint a Wilcoxon-féle előjeles rangpróba. Szignifikánsnak tekintettünk egy eredményt $\mathrm{p}<0,05$-nál.

\section{Eredmények}

Vizsgálatunkban a résztvevők átlagéletkora 32,53 év (SD: \pm 6,12 év; minimum-maximum: 19-50 év) volt, míg a kitöltés idejére vonatkozó átlagos testsúlyuk $66,06 \mathrm{~kg}( \pm 13,57 \mathrm{~kg} ; 44-118 \mathrm{~kg})$, átlagtestmagasságuk $1,65 \mathrm{~m}( \pm 0,07 \mathrm{~m} ; 1,48-1,86 \mathrm{~m})$ volt. A testsúlyból és a testmagasságból számított átlagos BMI-értékük 23,98 $\mathrm{kg} / \mathrm{m}^{2}\left( \pm 4,30 \mathrm{~kg} / \mathrm{m}^{2} ; 17-38 \mathrm{~kg} / \mathrm{m}^{2}\right)$. Ezen érték alapján mintánk 10\%-a (20 fó) az elhízott kategóriába (BMI $\geq 30 \mathrm{~kg} / \mathrm{m}^{2}$ ) tartozott. Az alanyok iskolai végzettségüket tekintve a következő megoszlást mutatták: $5 \%$ rendelkezett 8 befejezett általános iskolai osztállyal, 4\% szakmunkásképzői végzettséggel, 26\% érettségivel, 32\% főiskolai oklevéllel, míg 33\% egyetemi diplomával. Foglalkozásukat tekintve 18 fó még tanulmányait végezte, 141 fő irodai alkalmazott volt vagy egyéb szellemi munkát végzett, 33 fó könnyü fizikai munkát (például: postás), míg 5 fó nehéz fizikai munkát (például: raktáros) végzett. A válaszadók 8,5\%-a (17 fö) még nem szült, mivel a terhesség idő előtt (átlag: 19. hét; minimum-maximum: 17-24. hét) megszakadt. A vizsgált személyek 4\%-ának ( 8 fó) volt előzőleg ikerterhessége, míg a fennmaradó 96\% (192 fö) egy gyermekkel volt várandós.

Mintánkban a rectus diastasis prevalenciája 46,5\% lett. A 200 fös minta átlagait tekintve, csak a köldök magasságában találtunk a normálnál nagyobb eltávolodást. Ezzel szemben a kóros kategória átlagai majdnem minden mérési ponton meghaladták a $3 \mathrm{~cm}$-t, egyedül a köldök felett $10 \mathrm{~cm}$-rel nem érték el azt. Az adatok átlagait az 1. táblázat mutatja be. Megvizsgáltuk, hogy az egyenes

1. táblázat A mért interrectus-távolságok $(\mathrm{mm})$

\begin{tabular}{lccccc}
\hline & $\begin{array}{c}\text { Köldök } \\
\text { felett } \\
10\end{array}$ & $\begin{array}{c}\text { Köldök } \\
\text { felett } \\
\text { cm-rel }\end{array}$ & $\begin{array}{c}\text { Köldök } \\
\text { magas- } \\
\text { sm-rel }\end{array}$ & $\begin{array}{c}\text { Köldök } \\
\text { alatt } \\
2,5\end{array}$ & $\begin{array}{c}\text { Köldök } \\
\text { alatt } \\
5\end{array}$ \\
\hline $\begin{array}{l}\text { Teljes minta } \\
\text { (n=200) }\end{array}$ & 20,28 & 27,12 & 33,24 & 28,36 & 24,75 \\
\hline $\begin{array}{l}\text { Normálcsoport } \\
\text { (n= 107) }\end{array}$ & 12,16 & 15,78 & 19,45 & 15,71 & 12,77 \\
\hline $\begin{array}{l}\text { Kóros csoport } \\
\text { (n=93) }\end{array}$ & 29,63 & 40,16 & 49,11 & 42,90 & 38,53 \\
\hline
\end{tabular}




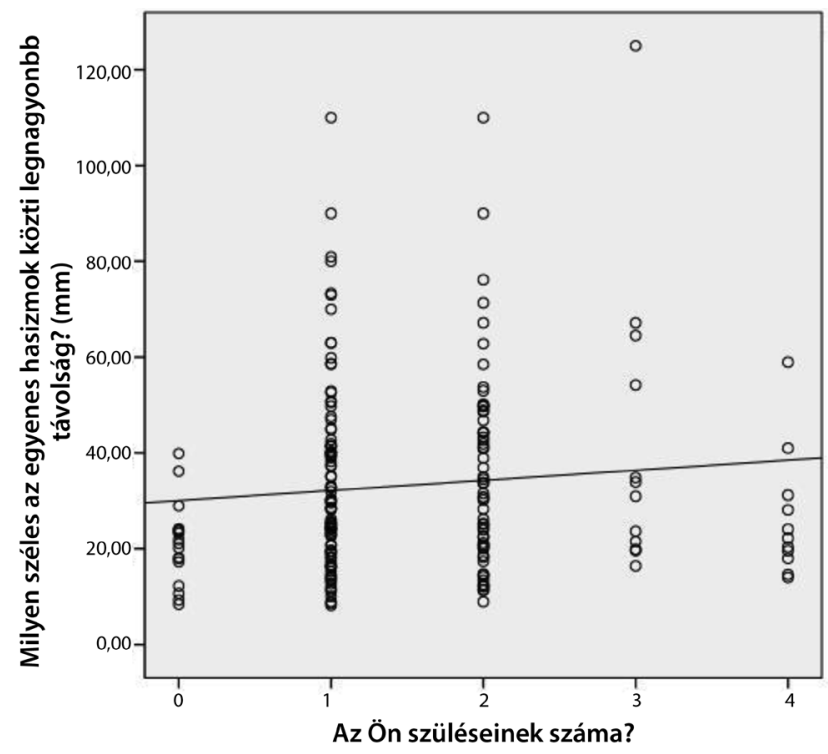

2. ábra $\quad$ Az interrectus-távolság és a szülések számának kapcsolata

hasizmok teljes hossza mentén hol figyelhetô meg a legszélesebb nyílás. A mintánkban legnagyobb arányban (164 fö) azok az esetek voltak, akiknél közvetlen a köldök magasságában tapasztalható a legszélesebb eltávolodás. Ez az állapot 22 fónél volt a legsúlyosabb, itt a legnagyobb távolság a köldök alatt $2,5 \mathrm{~cm}$-rel volt megfigyelhetô, míg 7-7 fónél a köldök fölött, illetve alatt 5-5 cm-rel jelentkezett.

Egy kockázati tényező kapcsán szignifikáns kapcsolatot $(\mathrm{p}=0,008 ; \mathrm{r}=0,277)$ fedeztünk fel: ez a szülések száma és az interrectustáv nagysága volt (2. ábra). A legnagyobb különbséget a még nem szült és az egyszer szült nôk csoportjai közt találtuk. Az első szülés mintegy 59\%-kal növelte meg az egyenes hasizmok közötti távolságot. Minden további szülés átlagosan 10\%-kal (körülbelül $2 \mathrm{~mm}$ ) növelte a rectus diastasis mértékét.

2. táblázat |A DRA és a lehetséges rizikófaktorok vizsgálata

\begin{tabular}{lcccccc}
\hline & $\begin{array}{c}\text { Mini- } \\
\text { mum }\end{array}$ & $\begin{array}{c}\text { Maxi- } \\
\text { mum }\end{array}$ & Átlag & Szórás & $\begin{array}{c}\text { p- } \\
\text { érték }\end{array}$ & r-érték \\
\hline Életkor & 19 & 50 & 32,53 & 6,116 & 0,061 & 0,133 \\
\hline Haskörfogat & 90 & 75 & 140 & 11,956 & 0,562 & $-0,062$ \\
\hline Súlygyarapodás & 3 & 30 & 13,95 & 4,968 & 0,206 & $-0,092$ \\
\hline Szülés ideje & 1988 & 2015 & 2012,52 & 4,262 & 0,974 & 0,002 \\
\hline Szülések száma & 0 & 4 & 1,5 & 0,937 & 0,008 & 0,277 \\
\hline $\begin{array}{l}\text { Terhességek } \\
\text { száma }\end{array}$ & 1 & 4 & 1,94 & 1,057 & 0,126 & 0,109 \\
\hline $\begin{array}{l}\text { Testtömeg- } \\
\text { index (BMI) }\end{array}$ & 17 & 38 & 23,98 & 4,304 & 0,129 & 0,108 \\
\hline $\begin{array}{l}\text { Újszülött } \\
\text { születési súlya }\end{array}$ & $<2500$ & $>4500$ & 3300 & 500 & 0,69 & 0,03 \\
\hline
\end{tabular}

$\mathrm{DRA}=$ rectus diastasis

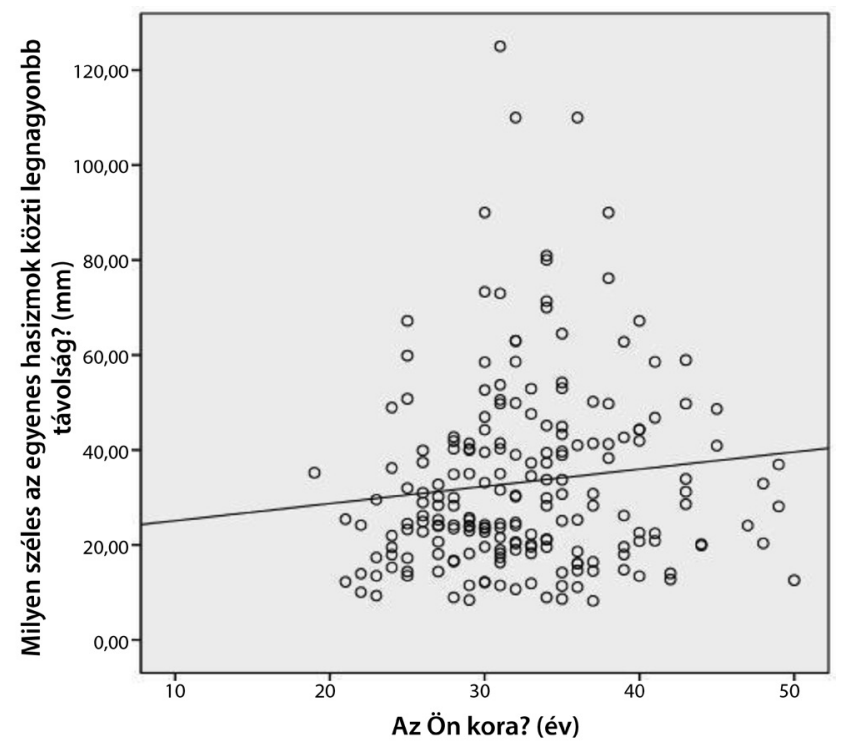

3. ábra | Az interrectus-távolság és az életkor kapcsolata

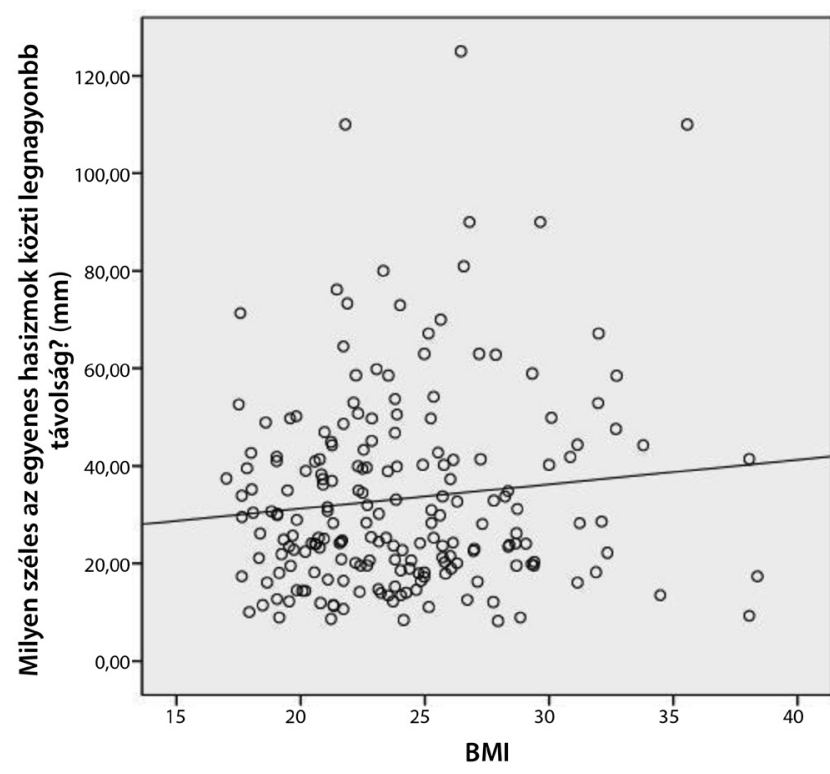

4. ábra | Az interrectus-távolság és a testtömegindex (BMI) kapcsolata

A további vizsgált rizikófaktor és a DRA között nem találtunk egyértelmú szignifikáns kapcsolatot (2. táblá$z a t)$. Érdemes azonban megjegyezni, hogy az életkor $(\mathrm{p}=0,061 ; \mathrm{r}=0,133)$, a testtömegindex $(\mathrm{p}=0,129 ; \mathrm{r}$ $=0,108)$, a terhességek száma $(\mathrm{p}=0,126 ; \mathrm{r}=0,10)$, valamint a szülés módja $(\mathrm{p}=0,058 ; \mathrm{r}=0,14)$ kapcsán a szignifikáns szinthez közeli eredményt kaptunk. Az életkor és a rectus diastasis közti korrelációt ábrázolja a 3. ábra, továbbá a testtömegindex és a DRA közti kapcsolatot szemlélteti a 4. ábra. A szülés módja és a rectus diastasis kapcsolatát jól szemlélteti, hogy míg hüvelyi szülés esetén a köldök magasságában átlagosan közel $32 \mathrm{~mm}$-nyire nyíltak szét az egyenes hasizmok, addig császármetszés esetén több mint 37 mm-nyire, ami 15\%os különbséget jelent. 
Az állapot és a lumbopelvicalis fájdalom kapcsolatát az Oswestry Disability Index kérdőívvel vizsgáltuk, amelynek eredménye szerint 7,7\%-ban tapasztaltak fájdalmat a kóros csoport tagjai. Eredményeink szerint jelentős egyenes arányú kapcsolat állt fenn az interrectus-távolság és a derékfájás között $(\mathrm{p}=0,039 ; \mathrm{r}=0,148)$. Ha a kérdőív kérdéseit egyesével megvizsgáltuk, az alvás ( $\mathrm{p}=$ $0,04 ; \mathrm{r}=0,148)$, valamint a szociális élet $(\mathrm{p}=0,046$; $\mathrm{r}=0,145)$ esetén találtunk szignifikáns kapcsolatot a vizsgált változók közt.

A saját készítésű kérdőívünk vizelettartási problémákra vonatkozó kérdései közül a medencefenék-izmok kontrakciójának maximális ideig való megtartása nem állt szignifikáns kapcsolatban az interrectus-távolsággal ( $\mathrm{p}=$ $0,616 ; \mathrm{r}=-0,039)$, azonban a $30 \mathrm{~s}$ alatti izomösszehúzódások száma igen $(\mathrm{p}=0,028 ; \mathrm{r}=-0,172)$. Amíg a normálkategória tagjai 31-szer tudták kontrahálni medencefenék-izmaikat fél perc alatt, addig a kóros csoportba tartozó nők 25-ször, ami 19\%-os különbséget jelent. A szintén vizeletinkontinenciát vizsgáló standardizált ICIQ-Urinary Incontinence kérdőívből nyert eredményeink nem lettek szignifikánsak $(\mathrm{p}=0,313$; $\mathrm{r}=0,072)$.

Az SF-36 kérdőív értékelése során szignifikáns kapcsolatot fedeztünk fel az interrectus-távolság nagysága és a fizikális egészség között $(\mathrm{p}=0,017 ; \mathrm{r}=-0,171)$. Minél nagyobb volt egy nô rectus diastasisa, annál inkább csökkent volt az életminősége. A fizikális egészség pontszámait négy alkérdésből számoltuk: a fizikai funkcióból, a testi fájdalomból, a korlátozott tevékenység fizikai állapot miatt kérdéskörből és az általános egészségből. Ebből a négy kérdésből egy esetben találtunk jelentős öszszefüggést: a szélesebb egyenes hasizmok közötti rés csökkent fizikai funkciókat eredményezett $(\mathrm{p}=0,004$; $\mathrm{r}=-0,202)$. A fájdalom $(\mathrm{p}=0,256 ; \mathrm{r}=-0,081)$, a fizikai korlát $(\mathrm{p}=0,476 ; \mathrm{r}=-0,05 \mathrm{l})$ és az általános egészség $(\mathrm{p}=0,546 ; \mathrm{r}=-0,043)$ kapcsán eredményeink nem lettek szignifikánsak.

\section{Megbeszélés}

A rectus diastasis a várandós nók jelentős részét érintő probléma. A 200 fós mintánkban 46,5\%-os volt a diastasis recti abdominis prevalenciája, vagyis majdnem minden második nőnek valamilyen mértékben szétnyílt az egyenes hasizma a várandósság következtében.

A kutatás során több rizikófaktort is megvizsgáltunk, amelyek feltételezhetően szerepet játszanak a nagyobb interrectusrés kialakulásában. Kilenc tényező, úgymint életkor $(\mathrm{p}=0,061)$, haskörfogat $(\mathrm{p}=0,562)$, súlygyarapodás $(p=0,206)$, testtömegindex $(p=0,129)$, terhességek száma $(\mathrm{p}=0,126)$, terhesség alatti sportolás menynyisége $(\mathrm{p}=0,279)$, szülés ideje $(\mathrm{p}=0,974)$ és módja $(\mathrm{p}=0,058)$, újszülött születési súlya $(\mathrm{p}=0,69)$ esetében találtunk különbséget a kóros és a normál távolsággal rendelkező nók csoportja közt, habár az eredményeink, hasonlóan Candido és mtsai kutatásához [4], nem voltak szignifikánsak. Vizsgálatunkban azonban egy rizikófaktorról ki tudtuk mutatni, hogy szignifikáns $(\mathrm{p}=0,008)$ kapcsolatban áll a rectus diastasissal: a szülési szám emelkedése az interrectusrést növelte. Ilyen következtetésre jutottak Spitznagle és mtsai is, akik a magasabb szülési számon kívül a magasabb terhességi számról, továbbá a korról is ki tudták mutatni, hogy összefüggésben áll a rectus diastasissal [14]. Lo és mtsai szintén kapcsolatot találtak a szülések száma és az egyenes hasizmok szétválása között, mint ahogyan a kor, a nagyobb magzati születési súly, az ikerterhesség és a császármetszés kapcsán is [22]. A kor tekintetében eredményeink alapján elmondhatjuk, hogy annak előrehaladtával nő az egyenes hasizmok között található rés nagysága. Ennek hátterében az állhat, hogy ahogy idősödik egy nő, úgy vállal nagy valószínúséggel egyre több gyermeket. Ez egyben azt is jelenti, hogy többször teszi ki a hasfalát a megnövekedett uterus és a magzat miatt fokozott feszülésnek, ami rectus diastasishoz vezethet $[14,23]$. Mivel a szövetekre ható feszítőerő a szülést közvetlenül megelőző időszakban a legnagyobb, a rectus diastasis is a harmadik trimeszterben alakul ki általában $[2,3]$. A szülés módja szerint is megvizsgáltuk a mintánkat, amelynek kapcsán azt az eredményt kaptuk, hogy a császármetszéssel szült nőknél jelentősebb mértékű diastasis jelentkezik. A BMI kapcsán szintén egyenes arányosságot találtunk, vagyis egy magasabb BMI-értékkel rendelkező nő esetében nagyobb, hasizom közötti távot is mértünk. Ennek oka lehetett a magassághoz viszonyított nagyobb testsúly, a mozgásszegényebb életmód, valamint az ezzel összefüggő jelentősebb hasi zsírréteg. Hasonlóan nem szignifikáns eredményeket állapítottak meg a BMI és a DRA kapcsán da Mota és mtsai is [3].

Az Oswestry Disability Index kérdőívvel vizsgált lumbopelvicalis fájdalom eredménye szerint 7,7\%-ban tapasztaltak fájdalmat a mintánk kóros csoportjába tartozó személyek, amely adatok teljes mértékben megegyeztek a Parker és mtsai által közölt 7,8\%-os eredményekkel [13]. A teljes kérdőív eredményeit néztük meg az egyes csoportok bontásában, és azt találtuk, hogy a kóros interrectus-távolsággal rendelkezőknél szignifikánsan magasabb százalékos eredményt értek el a válaszadók, mint a normál távú csoport tagjai. Ez a gerincoszlopot csökkent mértékben tartó hasizmok miatt lehetséges [24].

A fájdalom erősségében nem találtunk szignifikáns különbséget, azonban az „Alvás”, valamint a „Társadalmi élet” kérdések esetén a csoportok válaszai jelentősen eltértek egymástól. A fájdalom alvással való kapcsolata magyarázható azzal, hogy a hasizmok közötti kóros távolság miatt fellépő derékfájás időnként megnehezítheti a válaszadók alvási képességét. Hasonló a helyzet a társadalmi élet kérdését illetően: az eltávolodott hasizmok csökkent támasztófunkciója miatt jelentkező fájdalom gátolhatja abban a kérdő́vet kitöltőt, hogy sportot űzzön vagy aktív életet éljen. 
A vizelettartási probléma vizsgálatára nem találtunk olyan szakirodalmat, amely ugyancsak az ICIQ-Urinary Incontinence kérdőívet használta volna. Parker és mtsai kutatásában erre az összefüggésre vonatkozóan a Pelvic Floor Impact Questionnaire, valamint a Pelvic Floor Distress Inventory kérdőíveket használták. Mindhárom kérdőív tartalmaz kérdéseket arra vonatkozóan, hogy a kitöltő milyen hétköznapi tevékenységek során tapasztalt vizeletvesztést, azonban az ICIQ-Urinary Incontinence arra is rákérdez, hogy ez milyen gyakran történik, illetve, hogy mennyi vizelet folyik el alkalmanként. Parker és mtsai azt az eredményt kapták, hogy a kóros és a kontrollcsoport vizeletinkontinenciával kapcsolatos értékei között szignifikáns különbség van. Vizsgálatunkban a két csoport eredményei szignifikánsan ugyan nem tértek el egymástól, azonban kis különbség felfedezhető volt az adatok közt. Ennek magyarázatául szolgál, hogy a hasizmok, illetve a medencefenék-izmok szinergizmusban múködnek. Rectus diastasis esetén az egyenes hasizmok múködésében valamilyen károsodás lép fel, aminek következtében az őket körülölelő rectushüvely is mechanikailag sérülni fog. A megváltozott fascialefutás a medencefenék-izmokat és azok múködését ronthatja, ami így a vizelet elcseppenéséhez vezethet $[13,23]$.

Csökkent fizikális egészséget tapasztaltunk az SF-36 kérdőív kitöltésekor a rectus diastasissal rendelkező nők esetén, mint ahogyan azt Zappile-Lucis is találta [12]. Egy alkérdéscsoport kapcsán, a fizikai funkció esetén szintén szignifikáns különbséget találtunk a csoportjaink között. Ha az összes általunk felhasznált kérdőív eredményeit együtt nézzük, a csökkent fizikai funkció magyarázata lehet, hogy ha a gerincoszlopot nem tartja elölről egy zárt hasizomzat, a gerinc statikája megváltozik, ami a funkciókat, a mozgástartományt csökkentheti, fájdalmat is okozhat, és ez a fizikai egészséget összességében ronthatja [25].

\section{Következtetések}

Elvégzett vizsgálataink alapján megállapíthatjuk, hogy majdnem minden második nőt érint a terhességgel öszszefüggő rectus diastasis. A lehetséges kockázati tényezők közül érdemes megemlítenünk az életkort, a szülések számát és módját, hiszen ezek kapcsán jelentkezett szignifikáns értékhez közeli eredmény. Méréseink során a köldök magasságában találtuk a legnagyobb távolságot az egyenes hasizmok között, amely érték majdnem elérte az $50 \mathrm{~mm}$-t. Eredményeink szerint a normálisnál nagyobb interrectus-távolság hajlamosít a derékfájásra, medencefenékizom-gyengeségre, ennélfogva egy csökkent életminőségre. Levont következtetéseink csak a vizsgálatunkba bevont alanyokra érvényesek, mivel nem reprezentálják a teljes populációt. A kutatás folytatásaként a későbbiekben érdemes volna egy nagyobb, véletlenszerüen választott mintán is elvégezni ezeket a méréseket, hogy pontosabb eredményekhez jussunk.
Anyagi támogatás: A közlemény megírása, illetve a kapcsolódó kutatómunka anyagi támogatásban nem részesült.

Szerzői munkamegosztás: G. S.: A beteganyag gyưjtése, a betegek vizsgálata, statisztikai próbák elvégzése, a kézirat megfogalmazása és szerkesztése, a hipotézisek és a konklúzió kidolgozása. M. Z.: A beteganyag biztosítása, a betegek adatainak elérhetővé tétele. T. P.: Közremúködés a kézirat szerkesztésében. F. I.: A beteganyag biztosítása, a betegek adatainak elérhetővé tétele. J. M.: Közremúködés a vizsgálat kidolgozásában. Á. P.: A statisztikai adatok helyességének ellenőrzése. G. J.: A beteganyag biztosítása, a betegek adatainak elérhetővé tétele. B. J.: A beteganyag biztosítása, a betegek adatainak elérhetővé tétele. H. M.: Témavezető. Lektorálás, a kézirat végső korrektúrázása. A cikk végleges változatát valamennyi szerző elolvasta és jóváhagyta.

Érdekeltségek: A szerzőknek nincsenek érdekeltségeik.

\section{Irodalom}

[1] Noble, E.: Essential exercises for the childbearing year. A guide to health and comfort before and after your baby is born. 3rd ed. (Ed.: Smith, D.) Houghton Mifflin Company, Boston, USA, 1988.

[2] Boissonnault, J. S., Blaschak, M. J.: Incidence of diastasis recti abdominis during the childbearing year. Phys. Ther., 1988, 68(7), 1082-1086.

[3] da Mota, P. G., Pascoal, A. G., Carita, A. I., et al.: Prevalence and risk factors of diastasis recti abdominis from late pregnancy to 6 months postpartum, and relationship with lumbo-pelvic pain. Man. Ther., 2015, 20(1), 200-205.

[4] Candido, G., Lo, T., Janssen, P. A.: Risk factors for diastasis of the recti abdominis. J. Assoc. Chart. Physiother. Womens Health, 2005, 97, 49-54.

[5] Hsia, M., Jones, S.: Natural resolution of rectus abdominis diastasis. Two single case studies. Aust. J. Physiother., 2000, 46(4), 301-307.

[6] World Health Organisation: World Health Statistics. 2015. Available from: http://apps.who.int/iris/bitstream/10665/170250 /1/9789240694439_eng.pdf

[7] Hungarian Central Statistical Office: Number of quick-births [Központi Statisztikai Hivatal: Élveszülések száma.] 2015. Available from: http://www.ksh.hu/docs/hun/xstadat/xstadat_evkozi/e_wns001.html [Hungarian]

[8] Bursch, S. G.: Interrater reliability of diastasis recti abdominis measurement. Phys. Ther., 1987, 67(7), 1077-1079.

[9] Mota, P., Pascoal, A. G., Carita, A. I., et al.: Inter-recti distance at rest, during abdominal crunch and drawing in exercises during pregnancy and postpartum. Phys. Ther., 2015, 101(Suppl. 1), e1050-e1051.

[10] Barbosa, S., Moreira de Sá, R. A., Coca Velarde, L. G.: Diastasis of rectus abdominis in the immediate puerperium: correlation between imaging diagnosis and clinical examination. Arch. Gynecol. Obstet., 2013, 288(2), 299-303.

[11] Benjamin, D. R., van de Water, A. T., Peiris, C. L.: Effects of exercise on diastasis of the rectus abdominis muscle in the antenatal and postnatal periods: a systematic review. Physiotherapy, 2014, 100(1), 1-8.

[12] Zappile-Lucis, M.: Quality of life measurements and physical therapy management of a female diagnosed with diastasis recti abdominis. J. Womens Health Phys. Ther., 2009, 33(1), 22. 
[13] Parker, M. A., Millar, A. L., Dugan, S. A.: Diastasis rectus abdominis and lumbo-pelvic pain and dysfunction - Are they related? J. Womens Health Phys. Ther., 2009, 33(2), 15-22.

[14] Spitznagle, T. M., Leong, F. C., van Dillen, L. R.: Prevalence of diastasis recti abdominis in a urogynecological patient population. Int. Urogynecol. J. Pelvic Floor Dysfunct., 2007, 18(3), 321-328.

[15] Papp, Z. (ed.): Textbook of obstetrics and gynaecology. [A szülészet-nőgyógyászat tankönyve.] Semmelweis Kiadó, Budapest, 2009. [Hungarian]

[16] Thompson, J. A., O'Sullivan, P. B., Briffa, N. K., et al.: Assessment of voluntary pelvic floor muscle contraction in continent and incontinent women using transperineal ultrasound, manual muscle testing and vaginal squeeze pressure measurements. Int. Urogynecol. J. Pelvic Floor Dysfunct., 2006, 17(6), 624-630.

[17] Czimbalmos, Á., Nagy, Zs., Varga, Z., et al.: Patient satisfaction study with SF-36 questionnaire, the definition of normal values in Hungary. [Páciens megelégedettségi vizsgálat SF-36 kérdő́ivvel, a magyarországi normálértékek meghatározása.] Népegészségügy, 1999, 80(1), 4-19. [Hungarian]

[18] Fairbank, J. C., Pynsent, P. B.: The Oswestry Disability Index. Spine, 2000, 25(22), 2940-2952.

[19] Kenyeres, B., Sarlós, D. P., Szántó, Á., et al.: Validation of the Hungarian version of the international consultation on incontinence questionnaire-urinary incontinence short form (ICIQ$\mathrm{UI} / \mathrm{SF}$ ) in females with lower urinary tract symptoms. Eur. Urol. Suppl., 2015, 14(6), e1256.
[20] Tadiparthi, S., Shokrollahi, K., Doyle, G. S., et al.: Rectus sheat complication in abdominoplasty: Assessment of its longevity and a review of the literature. J. Plast. Reconstr. Aesthet. Surg., 2012, 65(3), 328-332.

[21] Emanuelsson, P., Gunnarsson, G., Strigård, K., et al.: Early complications, pain, and quality of life after reconstructive surgery for abdominal rectus muscle diastasis: a 3-month follow-up. J. Plast. Reconstr. Aesthet. Surg., 2014, 67(8), 1082-1088.

[22] Lo, T., Candido, G., Janssen, P.: Feature articles-diastasis of the recti abdominis in pregnancy: risk factors and treatment. Physiother. Can., 1999, 51(1), 32-37.

[23] Rett, M. T., Braga, M. D., Bernardes, N. O., et al.: Prevalence of diastasis of the rectus abdominis muscles immediately postpartum: comparison between primiparae and multiparae. Rev. Bras. Fisioter., 2009, 13(4), 275-280.

[24] Tulman, L., Fawcett, J.: Recovery from childbirth: Looking back 6 months after delivery. Health Care Women Int., 1991, 12(3), 341-350.

[25] Illés, $S$. T.: Low back pain: when and what to do. [A derékfájás: mikor és mit tegyünk?] Orv. Hetil., 2015, 156(33), 1315-1320. [Hungarian]

\section{KOSSUTH ZSUZSANNA EMLÉKÉV - 2017 A Magyar Ápolók Napján kitüntetettek}

A Magyar Országgyűlés, a Magyar Ápolási Egyesület kezdeményezésére 2014-ben február 19-ét, Kossuth Zsuzsánna születésének évfordulóját a Magyar Ápolók Napjának nyilvánította. Azóta ezen a napon kerül sor a kiemelkedő szakmai teljesítményt nyújtó szakdolgozók kitüntetésére.

\section{Kossuth Zsuzsánna-díjban részesültek: \\ Bognár Márta, ápolási koordinátor \\ Koszta Julianna, osztályvezető főnővér \\ Lukács Lászlóné, nyugalmazott ápolási igazgató}

A Kossuth Zsuzsánna-díjat a Magyar Ápolási Egyesület 1998-ban, a szabadságharc 150. évfordulójának évében alapította a kiváló szakmai munka és az ápolás, az ápolók, valamint ápolói közösségek létrehozása érdekében kifejtett, az egyesület keretében végzett kiemelkedő tevékenység elismeréséért.

\author{
Az Emberi Erőforrások Miniszterétől Pro Sanitate-díjat vehetett át: \\ Barti Péterné \\ Bodáné Gyürü Vanda \\ Deák Gyuláné \\ Kóczián Éva Erzsébet
}
Az Emberi Erőforrások Miniszterétől Elismerő Oklevelet kapott:
Bárányné Koncz Katalin
Baráth Ágnes
Benczik-Tóth Eszter Éva
Berkiné Kossuth Anett
Boros Istvánné
Kalcsó Péterné
Kókai-Nagy Ferencné
Lőrincz Katalin

(Gitta Stefánia, Pécs, Zója utca 1/A, X/31., 7624 e-mail: gitta.stefania@gmail.com)

z Orvosi Hetilap Szerkesztősége gratulál a kitüntetetteknek. 